\title{
Coconut inflorescence sap
}

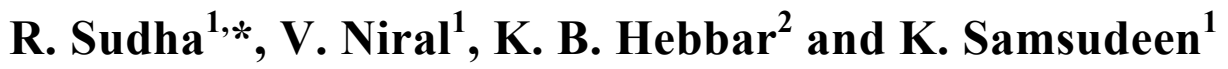 \\ ${ }^{1}$ Division of Crop Improvement, ICAR-Central Plantation Crops Research Institute, Kasaragod 671 124, India \\ ${ }^{2}$ Division of Crop Physiology, ICAR-Central Plantation Crops Research Institute, Kasaragod 671 124, India
}

Coconut inflorescence sap (neera) is the sweet, oysterwhite coloured sap collected from the immature coconut spadix (inflorescence). It is a natural health drink and a rich source of sugars, proteins, minerals, antioxidants and vitamins. Besides being used as a nutritional drink, it is used as raw material for value-added products like natural coconut sugar, palm syrup, jaggery and honey, which have high potential in domestic and international markets. Frequent price fluctuations of major products like nut, copra, oil, etc., call for product diversification in coconut farming. Hence neera/coconut inflorescence sap provides a huge opportunity for higher income to the coconut farmers, making coconut farming a profitable venture. In neera tapping, many factors have to be considered to obtain economic benefit. This review covers some of the factors influencing the neera quantity and quality. This information will help researchers plan research strategies to improve the sap characteristics for commercial utilization.

Keywords: Coconut inflorescence sap, diversification, neera, tapping, value addition.

Coconut (Cocos nucifera L.) is a widespread, economically important palm of the humid tropical regions. It grows well at below $1000 \mathrm{~m}$ altitudes and near the coastal areas between the latitudes $20^{\circ} \mathrm{N}$ and $20^{\circ} \mathrm{S}$ of the equator. It probably originated in the South-West Pacific or Indian Ocean and was domesticated in Malaysia and on the coasts and islands between South East Asia and Western Pacific and is spread across more than 90 countries. India is a leading country in coconut production and productivity in the world. The main coconut producing countries are Indonesia, Philippines and India. In India, annual coconut production is 23,904 million nuts from 20.8 lakh hectare area and the productivity per hectare is 11,481 coconuts ${ }^{1}$.

The diversity of products derived from the coconut palm is remarkable, viz. edible kernel, oil, shell, tender coconut water, fibre, building material from the frond and trunk, edible 'heart-of-palm' or cabbage from the growing point, sap from inflorescence, sugar, fuel, and the industrial uses include soaps, detergents and bio-diesel. All these provide the rationale for the title 'The Tree of Life'.

\footnotetext{
*For correspondence. (e-mail: rsudhahort@yahoo.co.in)
}

Among the products from coconut, inflorescence sap is the most remunerative product for farmers. Coconut inflorescence sap tapped from the unopened spathe or inflorescence of the coconut, is one of the versatile food products derived from coconut. It can be used as a nutrient-rich health drink and also be processed to syrup, honey and coconut sugar. It is a natural sugar containing health drink and a rich source of minerals, amino acids and vitamins.

Globally, neera and its value-added products are produced and marketed on a commercial scale by all the chief coconut producing countries except India. The major countries involved in the field are Philippines, Indonesia, Thailand, Malaysia, Sri Lanka and Vietnam. USA, Norway, Canada, Middle East, France, Japan, Australia, South Korea and New Zealand are the major export destinations. Export of neera and coconut sugar at natural products has shown an increasing trend in Philippines, Indonesia and Thailand. India is one among the three major coconut producing countries along with Indonesia and Philippines. Malaysia and Sri Lanka have also ventured into the production of neera and coconut sugar and these countries are far behind India in coconut production. Hence promoting coconut inflorescence sap production will definitely contribute to the GDP and the rural economy of the country. It will generate employment and ensure regular income to the coconut farmers and the neera tappers. Different value-added products from coconut inflorescence sap can establish niche markets for each product $^{2}$.

The yield of coconut inflorescence sap and its biochemical constituents varies considerably from palm to palm, spadix to spadix and season to season; it also varies based on growing conditions of the palm and skill of the tapper. This paper reviews the scientific studies carried out on coconut inflorescence sap yield and quality and factors influencing sap production, and serves as a guide to researchers for planning research strategies to improve the yield and quality of neera in different regions.

\section{Selection of palm for sap production}

Selection of palms for tapping neera is an important activity and plays an important role in their economic yield. Several factors are to be considered while selecting a palm for neera production. Vigorous middle-aged trees with a close set crown and more number of leaves with 
strong and short petioles are to be selected. The trees which produce spadices regularly and carry more number of female flowers in each spadix are to be preferred. The trees receiving good supply of moisture are to be preferred as they have been found to yield comparatively larger quantity of sap for a longer period.

In general, wide variation has been reported from palm to palm for sap yield within a variety, with sap yield varying from $200 \mathrm{ml}$ to $1500 \mathrm{ml} \mathrm{palm}{ }^{-1}$ day $^{-1}$. This may be due to the variability in the genetic potential of the coconut palms. Nathanael ${ }^{3}$ listed few criteria such as long internodes, uniform production of inflorescence and thin inflorescence sheaths for selecting palms for high sap yield.

According to Magat ${ }^{4}$, trees with more number of nuts and aged around 40 years produce plenty of neera. In such palms, the annual yield of neera varies from 300 to 400 litre. Dwarf palms with large volume of tender nut water with good flavour and higher content of total and reducing sugars, and tall palms producing nuts with higher proportions of both kernel (over 30\%) and husk (over $40 \%$ ) were reported to be suitable for tapping since such palms produce plenty of neera.

In Sri Lanka, neera tappers traditionally use some visual criteria such as more number of fronds and long and relatively thin inflorescence sheaths, which facilitate the bending of flower stalks without splitting. These parameters ensure sustainably high neera yields ${ }^{5}$.

Jnanadevan ${ }^{6}$ reported that young, high yielding and well cared for palms were found to yield high quantity of neera under Indian conditions and also reported that healthy, high yielding tall palms under good management could yield 50 litre of neera per inflorescence per month.

However, getting reliable results with such qualitative selection criteria is not possible. Quantitative studies to decide the criteria for selection of potential palms for high neera yields have not been reported and hence this merits further studies.

\section{Method of tapping}

Tapping coconut palm for the collection of neera is an age-old profession. Tapping is the process of artificially extracting sap from the unopened spadix. In India, the Thiyas of Malabar have been traditionally connected with coconut and are acclaimed experts in tapping from time immemorial. Different methods of tapping are followed in various parts of the world for the extraction of inflorescence sap. However, the principle is the same. A complete description of the method of collecting sap and uses of inflorescence sap has been provided by Child ${ }^{7}$. The suitability of the stage of inflorescence for tapping is judged by the swelling of the base of the spathe, owing to the development of female flowers inside the spathe. After selection, the spathe is trained for tapping by uni- form beating all over the length, twice a day, in the morning and evening. Then the spathe is tied along its length to prevent the burst opening of the spathe. After a week, about $7-10 \mathrm{~cm}$ length of the spathe is cut off and the exposed surface is pounded with the handle of the tapping knife. This operation is continued in the morning and evening for about a week. The tapper then cuts a thin slice off at the end of the spathe, both in the morning and evening or once a day. The above operation is continued for a few days till the sap begins to trickle. When the sap begins to flow, then an earthen pot smeared with lime is hung to the spadix so as to collect the sap. The period of sap flow varies from about 10 to 25 days $^{8}$. When the flow of sap commences, to collect the sap, a thin slice is cut-off in the spadix both in the morning and evening. A single spathe is thereby tapped until it is reduced to a stump of about $10-15 \mathrm{~cm}$ in length. About three weeks before reaching this stage, a subsequent spathe is prepared to ensure continuity of sap production in the palm being tapped. The tapping can be continued without any break for a period of one year on good, healthy palms ${ }^{9}$.

There are 44 developmental stages of a floral branch in the coconut palm. These stages range from the rudimentary initials to the cluster of ripe drupes as harvested. In this series, stage 22 represents the suitable stage of the spathe for tapping. At this stage, the spathe is so tender that it can easily bend slowly ${ }^{10}$.

In Sri Lanka, it has been reported that a tapper climbing the palms individually, can tap 25 to 30 palms in a working day. On the other hand, in tapping groves, where the palms are connected by aerial ropeways, a tapper can tap about 75 to 90 palms a day, provided he has an assistant on the ground to bulk the neera that is collected and let down by ropes ${ }^{9}$. In India, the individual palms are climbed by trained tappers for tapping.

Levang $^{11}$ reported that the scars in the spathe heal and the flow of sap stops when slicing is stopped for one or two days; then another two weeks would be necessary for restoring the disrupted sap flow in the inflorescence. Jnanadevan ${ }^{6}$ also stated that, when the spadix is not sliced for two days, a healing latex exudes from the cut wound, which hinders the sap flow and a further two weeks of tapping period is required to restore normal sap flow. Sometimes a closed spadix may not recover and may have to be abandoned altogether. Hence, tapping an inflorescence should be a continuous activity; even a day or two of rest for the harvester may lead to a yield loss of 15-20 days. Hence tapping activity performed by a team of neera tappers is important, so that members in a team can substitute each other.

The time taken from commencement of tapping to dripping of sap and yield of sap depend on the skill of the tapper, the tapping method, the prevailing season and nature of the palm. Hence at every stage, expertise of the staff is of prime importance. 


\section{Yield of sap}

There was substantial variation in the yield of sap from different trees, and from different spathes of the same trees during different seasons of the year, and the yield obtained in the mornings and evenings. There was also variation in yield due to the method of manipulating the spathes $^{12}$.

The sap flow from one inflorescence persists for about a month or at times even more. During this period, the second spadix is also ready for sap production. In general, the tapping activity is continued for six months and at a time, three spathes on the same tree are tapped. In Sri Lanka, it is usual to tap palms for eight months of the year and give a rest for four months. The maximum neera yield is usually achieved in the third month after the initiation of tapping ${ }^{13}$.

In India, a maximum of 18 litre of sap per spadix per month has been recorded. Palms yielding more number of nuts have been found to be high neera yielders. Such palms yield up to 300 litre of sap for a period of six months of tapping with an average yield of about 50 litre of sap per spadix. The average yield of neera per palm per day is about 1.5 litre. In Sri Lanka, on selected vigourously growing trees, the sap yield recorded per spadix was 49.5 litre during an average tapping period of 31.2 days. In the Phillippines, it was found that trees in good condition produce about 400 litre of sap per annum and it was higher when the palms were about 40 years old. Young palms often produce less than 300 litre. In an experiment with tapping of 100 trees, a daily total of 1.38 litre per tree was obtained. When calculated in 12 hour periods, during the day time, the sap flow was 0.64 litre and during night it was 0.74 litre $^{13}$.

In a tapping experiment conducted at CPCRI, Kasargod, the daily average yield of neera per palm was observed to be 1.59 litre. Higher sap production has been reported from Chittur taluk in Palakkad, Kerala; the sap yield per day was three litre on an average. Further, there are reports of coconut palms growing on paddy bunds, with neera yield of up to 7 litre per day. It was also reported that the trees producing barren nuts yield as much juice as trees producing normal nuts ${ }^{14}$.

Coconut varieties, environmental and management factors have a substantial influence on neera yields ${ }^{9,12}$.

\section{Seasonal influence on yield of sap}

In general, there is no definite season for tapping of inflorescence sap since the coconut regularly produces spadix in consecutive axils of the leaves. Hence tapping can be carried out throughout the year. However, a tree yields maximum quantity of sap during certain seasons of the year. In India, there are two major periods of tapping, viz. dry weather period (November-March) and wet weather period (April-October). Generally tapping is practiced for six months in a set of trees. If the tree is vigorous, tapping may be prolonged for even two years. In other countries like Philippines, Ceylon and Pacific Islands, palms are continuously tapped for a good number of years. Some trees have been neera yielders throughout their life period.

There is significant variation in the sap yield from season to season. The flow of sap increases during cloudy weather and gradually reduces during dry weather ${ }^{8}$. Pate $^{15}$ observed that when tapping commenced during April, the palms gave minimum quantity of sap during September to December and after that there was an increase in sap yield. He also reported that during the north-east monsoon, the sap yield was minimum, since during this period, the spathes invariably burst open before attaining the proper stage for tapping. It was also reported that early flow, higher yield and maximum duration of sap flow was observed in April-tapped palms. In Sri Lanka, coconut palms could be tapped for indefinite number of seasons as long as the rainfall was sufficient and the palms were rested for four months in a year. In the drier areas however, the spathes after 3-5 consecutive seasons of tapping were reported to progressively diminish in size and eventually abort. Woodroof ${ }^{13}$ reported that in one tapping day, the yield varied from $1 \frac{1 / 4}{\mathrm{pt}}$ per day in dry areas to $6 \mathrm{pt}$ per day in wet districts. The average daily yield per palm is about $2.5 \mathrm{pt}$ with a high yield of $33 / 4 \mathrm{pt}$ and a low of $2 \mathrm{pt}$. Trees tapped in November yielded an average of $36 \mathrm{pt}$ and those tapped in April yielded $30.5 \mathrm{pt}$ when the tapping period averaged 31 days. Some dilution of neera was also observed during wet weather.

At ICAR-CPCRI, Samsudeen et al. ${ }^{16}$ observed the highest sap production of 1043 and $1003 \mathrm{ml}$ per palm per day during post-monsoon (October-November) and monsoon (June-September) periods respectively. Sap production was lowest during summer months (March-May), but was statistically on par with the sap production in winter.

The rate of sap collection also differed between day and night. Sap generally flows more during the night than during the day time. Khieu Borin and Preston ${ }^{17}$ and Khieu Borin ${ }^{18}$ reported that the sap flow was higher during cool nights. In a study conducted at Philippines, it was found that the neera flow varied with the time of the day. It was highest between 8 a.m. and 10 a.m. and lowest between 1 p.m. and 2 p.m. The flow of the sap is linked to the water transpiration of the palm ${ }^{19}$. This justifies the reason for the flow of sap being high during the night.

\section{Varietal influence on yield of sap}

The high yielding coconut palms with reference to the production of nuts are not necessarily high sap yielders ${ }^{20}$. 
The dwarf palms have also been claimed to be highly suitable for tapping. The advantages such as their short stature and the possibility of higher density of dwarf palms in a unit area, are likely to compensate for the comparatively low sap yield of individual palms.

Jack and Sands ${ }^{21}$ stated that the sap yield of a dwarf palm ranges from 0.28 to 3.4 litre per day. They also reported that, tapping of dwarf palms is advantageous compared to tall palms since the dwarf palms commence production of sap earlier because of their early flowering nature and also their sap is sweeter than tall palms.

Nathanael $^{3}$ reported that in Sri Lanka, the nana (dwarf) variety is uneconomical for tapping while the yield potentialities of the typica (tall) make it eminently suitable for this purpose. The average daily yield and the total yield per palm, for 365 days tapping period for the typica variety are $1,582 \mathrm{ml}$ and 577.5 litre respectively, whereas for hybrids the yields are $2,177 \mathrm{ml}$ and 791.7 litre. $\mathrm{He}$ concluded that higher sap yield in hybrid was due to more number of spadices tapped (17.7) compared to the typica (11.7).

In Malaysia, studies on tapping of dwarf palms recorded a sap yield of 0.3-3.4 litre per day and the neera was sweeter and more palatable than that of the tall palms. In Sri Lanka, it was shown that a tapping period of more than four months resulted in a severe physiological set back and the yield per day went down to 0.3 litre and per spadix to 8.5 litre. Hence the dwarf palms were not considered commercially feasible for tapping. However, the dwarf palms of Sri Lanka and Malaysia were totally different and some of the dwarf palms like the Malayan dwarf may prove ideal for tapping. This aspect needs further research ${ }^{13}$.

In Sri Lanka, Jeganathan ${ }^{22}$ studied the sap producing capacity of tall, dwarf and hybrid $(\mathrm{T} \times \mathrm{D})$ coconut palms. The study reported that the hybrid produced 346 litre of sap per hectare per day, whereas typica produced 247 litre and pumila produced only 74 litre. He reported that the difference in the sap production between hybrid and typica was due to the higher number of spadices in the hybrid. He also reported that varieties of tall coconut palms yielded double the quantity of sap as that of dwarf palms and were more resistant to pests and abiotic stresses such as drought and wind because of their well developed root system.

Secretaria $^{23}$ studied the effect of sequential tapping of sap and nut production scheme in six coconut hybrids and cultivars at two experimental sites at Zamboanga City in Philippines. The results revealed that dwarf $\times$ tall hybrids and a Laguna tall cultivar gave significantly higher sap and nut yield compared to the Catigan dwarf and Catigan dwarf hybrid $(\mathrm{CAT} \times \mathrm{CAT})$ and the Tacunan dwarf cultivar.

In Sri Lanka, studies on tapping revealed that hybrids yielded more neera than the ordinary talls. The total yield of 792 litre was recorded for a tapping period of 365 days in the hybrids compared to 577 litre in the ordinary tall. During the period of tapping, 19 spadices were available in hybrids as against 15 in ordinary tall. Tapping was generally sustained for 10-11 months in Thailand, and certain high sap-yielding cultivars have been reported. In those palms, the daily neera yield was up to four litre per spathe and the duration of sap production was 30 days. Thalaeba, Suricha, Saiboa, Theung Bong, Kathi and Khi Kai are the high sap-yielding local varieties of Thailand. In Philippines the local variety Coconino, a dwarf type, was found to produce a sap yield of $400 \mathrm{ml}$ of neera per day $^{4}$. In India, Laccadive Ordinary, Andaman Ordinary and Laccadive Micro were found to be the best, yielding more than twice the quantity of juice than the West Coast Tall $(\mathrm{WCT})^{14}$.

According to Konan et $a l .{ }^{24}$ in Cote d'Ivoire, the hybrid variety PB 113 was recommended for the production of neera followed by the hybrid variety $\mathrm{PB} 121$ which is also a high yielder of nuts with disease resistance. The Malayan Yellow Dwarf (MYD) gave better nutritious sap and refreshing tender nut.

Recent studies at ICAR-CPCRI, reported higher inflorescence sap yield in WCT compared to Chowghat Orange Dwarf, with a single inflorescence being tapped for one and half to two months ${ }^{25}$. Samsudeen et al. ${ }^{16}$ studied the influence of variety on the inflorescence sap production and sap quality in three coconut varieties and a hybrid, viz. WCT (Kera Keralam), Laccadive Ordinary Tall (Chandra Kalpa), Chawghat Orange Dwarf (COD) and a hybrid COD $\times$ WCT (Chandra Sankara). The study revealed that sap production in tall varieties is better than dwarf varieties, with an average sap production of 960 and $880 \mathrm{ml}$ being recorded in WCT and Chandra Sankara hybrid respectively. Sap production in COD was very low and it was reported that dwarf varieties were not suitable for commercial tapping of inflorescence sap ${ }^{16}$. Subsequent observations on 14 accessions at CPCRI, Kasaragod indicated variation in sap quality and quantity in different accessions. Highest sap yield was recorded in Laccadive Ordinary Tall, followed by Nigerian Green Dwarf (though collected as a dwarf accession, it has relatively a taller plant habit), Federated Malay States Tall, WCT and Fiji Tall ${ }^{26}$. In general, sap yield was observed to be less in dwarfs. Among the studied accessions with dwarf plant habit, sap yield was low in Chowghat Orange Dwarf followed by Gangobandom, whereas MYD and Cameron Red Dwarf were observed to produce relatively higher quantity of sap. Jnanadevan ${ }^{6}$, while stating that tall palms yielded more sap than dwarf palms, also reported that the Malayan dwarf palms being relatively healthier, gave relatively higher sap yield.

A study was conducted with four varieties of coconut namely MYD, Keraganga, WCT and Kerasree and results revealed that the tall variety WCT had the highest sap yield of $3.14 \mathrm{lday}^{-1}$, which was significantly higher than the hybrids and dwarf varieties ${ }^{27}$. 


\section{Stimulation of sap}

Child $^{7}$ stated that, when the neera is in full flow, smearing a mixture of bruised leaves containing saponin at the time of shaving of the slice from the end of the spathe, can stimulate the flow. In some other places and in India, use of paste of Achil tree (Aposora lindleyana) or mucilaginous leaf, such as that of Hibiscus, is also reported $^{15}$.

Ranasinghe and Waidyanatha ${ }^{28}$ studied the effect of Ethrel application on sap yield in Sri Lanka. Ethrel @ $2.5 \%$, when applied at the axis of the tapping inflorescence, increased the sap flow and total sugar content of the sap. The rate of sap flow was significantly higher in palms treated with Ethrel. In general, during tapping, the spadix end is injured and subsequently the phloem sap which is rich in sugar surges toward the cut end, and as a natural process in plants, callose may be formed to seal the pores in the sieve element to prevent further loss of sap. Ethrel may inhibit the formation of callose, thereby increasing the duration of sap flow and flow rate. It is also reported that ethrel synthesizes $\beta$-1-3-glucanase, an important enzyme involved in degradation of sieve-tube callose.

\section{Influence of biotic and abiotic stress on tapping and yield of sap}

Eden Green and Waters ${ }^{29}$ studied the properties of the phloem sap in lethal yellowing-affected and healthy palms. There is low yield of sap or no sap production from lethal yellowing-affected palms since most of the leaves are affected by yellowing. This may be due to the disturbance in the phloem function. The highest concentration of MLO (phytoplasm) occurred at sink sites, such as expanding leaf base tissues, inflorescence and root tips. The mechanical blockage of phloem by MLO or callose may be the reason for reduced exudation. Similar conclusions have been drawn in other woody perennials $^{30}$. McDonough and Zimmermann ${ }^{31}$ detected a reduction in xylem tension in diseased palms, which favours phloem water potential.

In India, tapping of root (wilt) affected coconut palms for a period of six months proved effective in reducing the severity of disease as evidenced by lower disease index of 12 against 34 in the case of diseased untapped control. The quantity of neera produced by the diseased palms was lower (43.5 litre) than the healthy palms (69.6 litre) $)^{32}$.

Experiments conducted at CPCRI, Regional Station, Kayamkulam revealed that the progression in disease index was lowered when mildly and moderately wiltaffected palms were subjected to tapping. They recorded a disease index of 0.92 and 3.53 respectively compared to 6.62 and 5.73 in untapped palms. Tapping was not effec- tive for reducing the disease intensity in severely affected palms (Table 1$)^{33}$.

Rajagopal et al $^{34}$ stated that the apparently healthy palms had a rate of inflorescence sap flow of $5 \mathrm{ml} \mathrm{h}^{-1}$ until 25 days, but shot up to about $22-25 \mathrm{ml} \mathrm{h}^{-1}$ at 32 days. This trend continued for 70 days followed by a rapid decline. Early diseased palm yielded a small quantity of sap initially $\left(<5 \mathrm{ml} \mathrm{h}^{-1}\right)$, but registered a peak by 22 days, with about $24 \mathrm{ml} \mathrm{h}^{-1}$. This was followed by a rapid decline in sap flow which ultimately ceased by 35 days. They also highlighted that, with the intensity of the disease, rate of sap flow decreased, which did not last beyond 23 days.

The Coconut Research Institute of Sri Lanka surveyed and identified the following abiotic stresses affecting sap yields, viz. low moisture stress, nutritional deficiencies, rain storms and winds ${ }^{35}$.

According to Samsudeen et al. ${ }^{16}$, rain positively influenced the sap production since higher sap production was observed during monsoon and post-monsoon periods. The sap flow increased only after middle of June indicating soil moisture build up that positively affected sap flow. Similar observations were recorded across different accessions in a subsequent study in India ${ }^{36}$.

\section{Influence of tapping on nut, copra and oil yield}

Magalon $^{37}$ and Fealy ${ }^{38}$ reported that a young coconut tree tapped continuously for 6-12 months for sugar production will then produce more number of nuts.

Patel $^{15}$ reported that tapping resulted in a significant increase in average nut yield in the palms where nut yield was below 70 nuts per annum per tree. A similar increase was also observed in untapped trees, except for the group below 30 nuts. He also reported that the difference between the average increase in the nut yields of tapped and untapped trees becomes insignificant, indicating that the effect of tapping lasted only for four years. It is general practice for neera tappers to tap poor-yielding palms for a season or two and then allow those palms to produce nuts. Tapping is again resumed in such palms when the yield commences to fall.

Table 1. Effect of tapping process on the severity of the disease

\begin{tabular}{lccc}
\hline $\begin{array}{l}\text { Stage of the } \\
\text { disease }\end{array}$ & $\begin{array}{c}\text { During initial } \\
\text { observation }\end{array}$ & $\begin{array}{c}\text { Disease index } \\
\text { during final } \\
\text { observation }\end{array}$ & $\begin{array}{c}\text { Increase } \\
\text { over initial }\end{array}$ \\
\hline $\begin{array}{l}\text { Tapped palms } \\
\quad \text { Mild }\end{array}$ & 7.54 & 8.46 & 0.92 \\
$\quad$ Moderate & 8.79 & 12.33 & 3.53 \\
$\quad$ Severe & 14.40 & 30.26 & 15.86 \\
$\quad \begin{array}{l}\text { Untapped palms } \\
\quad \text { Mild }\end{array}$ & 4.64 & 11.26 & 6.62 \\
$\quad$ Moderate & 6.88 & 12.63 & 5.73 \\
$\quad$ Severe & 11.00 & 20.29 & 9.29 \\
\hline
\end{tabular}


Piggott $^{39}$ reported that by tapping a palm, the yield is reduced. A spadix so treated cannot produce nuts because the flowers are destroyed. It is usual to tap every spadix on the palm from 6 months to 6 years or more. When tapping is stopped there is every chance that the yield of nuts will increase slightly for a few years before returning to normal.

Mathes ${ }^{40}$ reported that the number of female flowers in tapped palms is higher than the untapped palms. A total of 48 female flowers per inflorescence were produced by the low-yielding palms after tapping, whereas only 16 and 20 female flowers per inflorescence were produced by the untapped high-yielding and very high-yielding palms respectively. The same trend was observed in percentage fruit set and number of developing fruits per bunch in tapped and untapped palms. The number of female flowers and fruits at the end of 4 months in tapped palms is about three times higher than that of the untapped high-yielding palms and double that of the untapped very high yielding palms.

A technique called sequential coconut toddy and nut production has been developed at the Davao Research Centre, Philippines. In this technique, the first half of the spathe is tapped and utilized for sap production and the second half is allowed for nut production since the female flowers that develop into mature nuts are situated in the second half of the spathe. Following this technique, about $50 \%$ lower nut and copra yields were observed than those in untapped palms. However, this technique is feasible and profitable for smallholders ${ }^{41}$.

Tapping has been found to improve the yield of medium and poor-bearing palms after it is discontinued, with the beneficial effects lasting for four years. In India, studies on tapping have indicated that tapping increases the yield, but only of poor-yielding palms. In the Philippines, the palms which were tapped produced more nuts for a year after tapping, and continued for a few years. But the copra of the nuts from such trees showed comparatively lower oil content. The reduction in oil content ranged from $14.32 \mathrm{~kg}$ to $25.79 \mathrm{~kg}$ per tonne of copra. In Malaysia also, similar results were reported. The nuts from the untapped palms contained $8.5 \%$ more copra and the copra contained $14.2 \%$ more oil compared to the nuts from the tapped palms ${ }^{42}$ (Table 2).

Table 2. Percentage and physical constants of copra/oil in tapped and untapped palms

\begin{tabular}{lccc}
\hline Constituents & $\begin{array}{c}\text { Untapped } \\
\text { palms }\end{array}$ & $\begin{array}{c}\text { Tapped } \\
\text { palms }\end{array}$ & Differences \\
\hline Weight of the meat per nut (g) & 511 & 490 & 21.0 \\
Moisture content of meat (\%) & 51.5 & 49.5 & 2.0 \\
Weight of copra per nut (g) & 253.2 & 242.5 & 10.7 \\
Weight of oil per nut (g) & 175.0 & 153.3 & 21.7 \\
Oil content of copra (\%) & 66.5 & 63.2 & 3.3 \\
\hline
\end{tabular}

Source: ref. 42 .
Studies on comparing nut producing and sap producing systems revealed that there is no significant association between sap yield and nut yield of coconut palm ${ }^{5}$.

\section{Correlation of tree parameters and yield of sap}

The correlations between the total yield of sap and the number of nuts, female flowers, leaves and spadices tapped were studied by Patel $^{15}$. Significant positive correlation between the sap and nut yield was observed when the number of female flowers was kept constant. The correlation between the number of spadices and the yield of sap was not significant. A positive correlation of coconut yield with rate of photosynthesis, number of leaves and chlorophyll content was observed ${ }^{43,44}$. However, correlations between the sap yield and physiological factors have not been reported to date. Sap flow in coconut depends on the variety and soil condition on which the palm is grown. It was reported that the depth and water holding capacity of the soil and leaf area of palm were positively correlated with higher sap yield ${ }^{45}$.

Samsudeen et al. ${ }^{16}$ reported that there was no correlation between sap production and weather parameters except in the case of wind velocity and evaporation. Wind velocity and evaporation showed significant negative correlation with sap production.

Konan et $\mathrm{al}^{24}$ accounted for a positive correlation between the duration of sap production and the length and median circumference of the spathe. Duration of sap production also recorded positive correlation with total volume of sap.

\section{Biochemical parameters of inflorescence sap}

Palm trees such as Nypa fruticans, Borassus flabelliform and Cocos nucifera are tapped for their high volume of sap, rich in sugar. The extracted sap can be used for preparing syrup, vinegar, sugar, alcoholic beverages and also for biofuel production. Compared to conventional crops such as sugarcane, maize, sugar beet, cassava and sweet potatoes, palm trees are able to produce higher yields of sugar. Fresh coconut inflorescence sap (FCIS) is used for its sugar and for alcoholic beverages by local people and was reported to be a highly nutritive and good digestive agent ${ }^{1}$. Fresh sap is rich in amino acids and vitamins ${ }^{46}$ (Tables 3 and 4). Many researchers have studied the chemical compounds of FCIS (Table 5).

A report from the Food and Nutrition Research Institute (Philippines) has given the nutrient and non-nutrient profile of coconut sap and states that coconut sap is rich in iron, zinc, calcium, sodium, potassium, dietary fibre and inulin. It also possesses phytonutrient content such as polyphenols, flavonoids and anthocyanidin. Clinical studies have shown that coconut sap has low Glycemic index. 
Differences in the biochemical constitution of sap were observed between two accessions, viz. WCT and COD. Total sugar $(6.39 \mathrm{~g} / 100 \mathrm{ml})$ and reducing sugar content $(0.24 \mathrm{~g} / 100 \mathrm{ml})$ and protein content $(0.05 \mathrm{~g} / 100 \mathrm{ml})$ were more in $\mathrm{COD}^{25}$.

Samsudeen et al. ${ }^{16}$ observed biochemical parameters in three varieties (WCT, LCT, COD) and a hybrid (COD $\times$ WCT) and reported that, total sugar was the highest in WCT, followed by LCT. Lowest total sugar content was recorded in COD. There was no significant difference in reducing sugar and protein content among the varieties tested, though reducing sugar was slightly higher in $\mathrm{D} \times \mathrm{T}$ and LCT. Protein content also did not show any significant difference among the varieties. Difference in quality of sap was noticed between sap collected during monsoon and winter in the case of WCT. The total sugar content was $4.31 \mathrm{~g} / \mathrm{ml}$ more during monsoon, while reducing sugar content was less by $0.85 \mathrm{~g} / 100 \mathrm{ml}$. Coconut

Table 3. Vitamin content in freshly gathered coconut sap

\begin{tabular}{lc}
\hline Vitamin & Value $(\mathrm{mg} / 100 \mathrm{ml})$ \\
\hline Thiamine & 77.00 \\
Riboflavin & 12.20 \\
Pyridoxal & 38.40 \\
Pantothenic acid & 5.20 \\
Nicotinic acid & 40.60 \\
Biotin & 0.17 \\
Folic acid & 0.24 \\
Inositol & 127.70 \\
Choline & 9.00 \\
Vitamin B12 & Trace \\
Vitamin C & 17.5 \\
\hline
\end{tabular}

Source: ref. 52 .

Table 4. Amino acid content of freshly gathered coconut sap

\begin{tabular}{lc}
\hline Amino acid & Value $(\mathrm{g} / 100 \mathrm{~g})$ \\
\hline Tryptophan & 1.27 \\
Lysine & 0.32 \\
Histidine & 1.19 \\
Arginine & 0.35 \\
Aspartic acid & 11.22 \\
Threonine & 15.36 \\
Serine & 8.24 \\
Glutamic acid & 34.20 \\
Proline & 3.52 \\
Glycine & 0.47 \\
Alanine & 2.56 \\
Valine & 2.11 \\
Methionine & - \\
Isoleucine & 0.38 \\
Leucine & 0.48 \\
Tyrosine & 0.31 \\
Phenylalanine & 0.78 \\
\hline
\end{tabular}

Source: ref. 53. sap collected from a tall variety (LCT) and a hybrid $($ WCT $\times$ GBGD) was analysed for total phenolic content and in vitro antioxidant activity. Total phenolic content was high in WCT $\times$ GBGD $\left(20.09 \mathrm{mg}\right.$ GAE $\left.100 \mathrm{ml}^{-1}\right)$ compared to LCT (18.91 mg GAE $\left.100 \mathrm{ml}^{-1}\right)$. The antioxidant activity of WCT $\times$ GBGD (3.39 and $\left.3.51 \mu \mathrm{M} \mathrm{ml}^{-1}\right)$ was found superior to LCT in terms of ascorbic acid and trolox equivalent $^{47}$.

A study analysing the biochemical parameters of four coconut varieties (WCT, Keraganga, Kerasree and MYD) revealed that the $\mathrm{pH}$ of the sap was near neutral (6.6-6.8), and electrolyte concentration was highest in WCT $\left(0.21 \mathrm{dS} \mathrm{m}^{-1}\right)$ and was on par with Keraganga $\left(0.19 \mathrm{dS} \mathrm{m}^{-1}\right)$ and Kerasree $\left(0.19 \mathrm{dS} \mathrm{m}^{-1}\right)$. WCT had the highest total sugar content, which was on par with MYD and Keraganga. Reducing sugar was highest in WCT. Phenol content was high in MYD (4.02 mg $100 \mathrm{ml}^{-1}$ ). The highest vitamin C content was in WCT and was on par with MYD and Kerasree. The total mineral content was the highest in WCT $(2.32 \%)^{27}$.

The differences in biochemical constitution of sap have also been reported based on the health of the palms. The studies carried out at CPCRI, Kasaragod indicated that the sugar content of sap was less in the root (wilt) diseaseaffected palms $(3.2 \%)$ as against $13.1 \%$ in the case of sap from healthy palms. This demonstrates the sugar metabolism of coconut palms in either synthesis or translocation. The study also clarified that the tapping has some effect in improving the phenolic contents of diseased palms $^{32}$. The reducing sugar content of the sap of diseased palms $(8.7 \%)$ was comparatively less than healthy palms $(12.9 \%)^{48}$.

Rajagopal et al. ${ }^{34}$ stated that the $\mathrm{pH}$ of sap from the day collection was higher than that from the night collection in both root (wilt) affected and healthy palms. It was high in disease-affected palms (7.2 during day and 6.5 during night) than healthy palms (6.9 during day and 6.1

Table 5. Biochemical and mineral composition of freshly collected coconut inflorescence sap (per $100 \mathrm{ml}$ )

\begin{tabular}{lcc}
\hline Biochemical parameters & Range & Average \\
\hline pH & $6.57-7.50$ & 7.18 \\
Total sugar (g) & $10.08-16.50$ & 15.18 \\
Reducing sugar (g) & $0.439-0.647$ & 0.554 \\
Amino acids (g) & $0.123-0.338$ & 0.245 \\
Protein (g) & $0.150-0.177$ & 0.165 \\
Sodium (mg) & $69.4-117.5$ & 90.6 \\
Potassium (mg) & $146.1-182.4$ & 168.4 \\
Phosphorus (mg) & $2.0-6.4$ & 3.9 \\
Manganese (mg) & $0.009-0.014$ & 0.012 \\
Copper (mg) & $0.028-0.035$ & 0.031 \\
Zinc (mg) & $0.018-0.026$ & 0.020 \\
Iron (mg) & $0.049-0.058$ & 0.053 \\
Phenolics (mg) & $4.80-5.40$ & 5.10 \\
Antioxidant activity (mM TE) & $0.299-0.355$ & 0.321 \\
\hline
\end{tabular}

Source: ref. 54. 


\section{REVIEW ARTICLE}

during night). The osmotic concentration of the sap from healthy palms was higher than root (wilt) disease affected palms. Besides, the reducing sugar content was less in disease-affected palms $\left(51.1 \mathrm{mg} \mathrm{g}^{-1}\right.$ during day and $24.6 \mathrm{mg} \mathrm{g}^{-1}$ during night) compared to healthy palms (52.0 $\mathrm{mg} \mathrm{g}^{-1}$ during day and $45.8 \mathrm{mg} \mathrm{g}^{-1}$ during night).

Chempakam et al. $^{49}$ found that the concentrations of cystine, leucine, glutamic acid and serine were less in the sap collected from root (wilt) disease affected palms than the healthy palms. However aspartic acid, arginine and tyrosine were high in the sap from diseased palms, and account for more than $50 \%$ of the total amino acids present. Even though the individual amino acids present showed variations, the total content was less in the diseased sap. Organic acids, viz. malonic acid and lactic acid and sugars, viz. glucose and galactose were high in sap collected from root (wilt) disease affected palms.

\section{Conclusion and future strategies}

Coconut palm is one of the economically important palms in the world and owing to its multipurpose nature, it can contribute in many ways for the sustainability of farming communities. With highly flexible prices of copra, it has become difficult for small farmers to depend on copra production alone for their livelihood. Hence diversification is a better option for sustainability of coconut growers. At present coconut inflorescence sap, as a health drink, has tremendous market potential in India as well as in other countries like Sri Lanka, Indonesia, Thailand, Myanmar, Africa, Philippines and Pacific Ocean Islands. Hence if promoted, it has tremendous market potential as a natural health drink and also as a raw material for different value-added coconut products like syrup, sugar, honey, etc., which have extensive export potential in developed markets like USA and the European region and this ensures the profitability of coconut cultivation and contribute to the sustenance and well-being of coconut communities.

However the criteria to select potentially high sapyielding coconut palms based on scientific studies have not been reported. Hence detailed studies on the stature of the palm, palm morphology, physiological and biochemical aspects of palm during tapping need to be carried out. Many studies were carried out on neera tapping and its characteristics $^{50,51}$. However, there are few reports comparing the sap production parameters from different cultivars and varieties. Therefore research on the quantity and quality of sap from different cultivars and varieties needs to be carried out. In addition, sap yield is influenced by the environment and weather parameters, which play a major role in the production of sap. Though certain prior studies have shown that the sap production depends on the variety and environment ${ }^{23,45}$, not much information is available on seasonal differences in coconut sap pro- duction in different cultivars/varieties. If coconut inflorescence sap production is to be promoted on a much larger scale, the research gaps need to be addressed on a war footing by providing scientific support to coconut communities to ensure the profitability of coconut inflorescence tapping for sap production.

1. Coconutboard.nic.in

2. Jose, T. K., Neera for the revival of coconut economy. Indian Coconut J., 2013, 56(1), 2-3.

3. Nathanael, W. R. N., Toddy yield from coconut palms in Ceylon. Ceylon Cocon. Quart., 1955, 6, 8-16.

4. Magat, S. S., Intercropping and toddy/sugar production in coconut-based farming systems: Possible integration with germplasm conservation and varietal improvement. In Promoting multipurpose uses and competitiveness of the coconut. Proceedings of Workshop (eds Batugal, P. A., Ramanatha Rao, V. and Bong, C.), 26-29 September 1996, Chumphon, IPGRI-APO, Serdang, Thailand, 1998, pp. 57-146.

5. Ranasinghe, C. S. and Silva, L. R. S., Photosynthetic assimilation, carbohydrates in vegetative organs and carbon removal in nutproducing and sap-producing coconut palms. Cocos, 2007, 18, 4557.

6. Jnanadevan, Coconut palms suitable for Neera tapping. Indian Coconut J., 2013, 56(1), 15-16.

7. Child, R., Coconuts, Longmans, 1964, 192.

8. Menon, K. P. V. and Pandalai, K. M., The Coconut Palm-A Monograph, Times of India Press, Bombay, India, 1958.

9. Nathanael, W. R. N., A tapping technique for the coconut palm. Ceylon Cocon. Plrs. Rev., 1966, 4(4), 87-99.

10. Banzon, Julian, Gonzalez, O., de Leon, S. and Sanchez, P., Coconut as Food, Philippines Coconut Research and Development Foundation, 1990.

11. Levang, P., Le cocotier est aussi une plante sucridlre. Ol: Sagineux, 1988, 43(4), 159-164.

12. Ranasinghe, C. S., Report of the Plant Physiology Division. In Annual Report of Coconut Research Institute, Sri Lanka, pp. 168169.

13. Woodroof, J. C., Coconuts: Production, Processing Products, The AVI publishing Company, Inc., Westport, Connecticut, 1970.

14. Rethinam, P., Sreekumar Poduval and Nanda Kumar, T. B., Coconut Products, Niseema Printers, Kochi, 2002.

15. Patel, J. S., The Coconut - A Monograph, Govt Press, Madras, 1938.

16. Samsudeen, K., Niral, V., Jerard, B. A., Berwal, M. K., Sugatha, P. and Hebbar, K. B., Influence of variety and season in the inflorescence sap production in Cocos nucifera L. J. Plant. Crops, 2013, 47(1), 57-61.

17. Khieu Borin and Preston, T. R., Conserving biodiversity and the environment and improving the wellbeing of poor farmers in Cambodia by promoting pig feeding systems using the juice of the sugar palm tree (Borassus flabellifer). Livestock Res. Rural Dev., 1995, 7(2); http://www.lrrd.org//rrd7/2/5.htm

18. Khieu Borin, A study on the use of the sugar palm tree (Borassus flabellifer) for different purposes in Cambodia. M Sc thesis, Swedish University of Agricultural Sciences, Uppsala, 1996, p. 67.

19. Loustau, D., Domec, J. C. and Bosc, A., Interpreting the variation in xylem sap flux density within the trunk of maritime pine (Pinus pinaster Ait.): application of a model for calculating water flows at tree and stand levels. Ann. Sci. For., 1998, 55, 29-46.

20. Pethiyagoda, U., Coconut inflorescence sap. Planter, 1979, 55(641), 390-397.

21. Jack, H. W. and Sands, W. N., Observations on the dwarf coconut palm in Malaya. Malay Agric. J., 1929, 17, 140-170.

22. Jeganathan, M., Toddy yields from hybrid coconut palms. Ceylon Coconut Quart., 1974, 25, 139-148. 
23. Secretaria, M. I., Ebuna, R. M., Madrazo, R. M., Magat, S. S., Maravilla, J. N., Santos, G. A. and Baylon, G. B., Sequential coconut toddy-nut production (SCTNP) scheme in different coconut cultivars and hybrids: production and processing of product. Philippine J. Crop Sci., 1998, 23(1), 76.

24. Konan, N. Y., Konan, K. J. L., Assa, R. R., Konan, B. R., Okoma, D. M. J., Allou, K. and Biego, G. M. H., Assessment of sap production parameters from spathes of four coconut (Cocos nucifera L.) cultivars in Côte d'Ivoire. Sustain. Agric. Res., 2013, 2(4), $87-94$.

25. Anon., Annual Report of ICAR-CPCRI, Kasaragod, Kerala, India, 2011.

26. Anon., Annual Report of ICAR-CPCRI, Kasaragod, Kerala, India, 2016.

27. Joseph Biju, Reghu, R. S., Gladis, R. and Aparna, B., Influence of coconut varieties on yield and quality of coconut inflorescence sap-neera. Indian J. Sci. Res., 2018, 19(1), 57-60.

28. Ranasinghe, C. S. and Waidyanatha, U. P. de S., Ethrel stimulation of inflorescence sap flow in tapped coconut (Cocos nucifera) palms. Exp. Agric., 2003, 39, 161-166.

29. Eden Green, S. J. and Waters, H., Collection and properties of phloem sap from healthy and lethal yellowing-diseased coconut palms. Phytopathology, 1982, 72(6), 667-672.

30. Catlin, P. B., Olsson, E. A. and Beutel, J. A., Reduced translocation of carbon and nitrogen from leaves with symptoms of pearl curl. J. Am. Soc. Hortic. Sci., 1975, 100, 184-187.

31. McDonough, J. and Zimmermann, M. H., Effect of lethal yellowing on xylem pressure in coconut palms. J. Palm Soc., 1979, 23(3), 132-137.

32. Anon., Annual Report of ICAR-CPCRI, Kasaragod, Kerala, India, 1986.

33. Anon., Annual Report of ICAR-CPCRI, Kasaragod, Kerala, India, 1987.

34. Rajagopal, V., Chempakam, B., Robert Cecil and Kamalakshy Amma, Studies on phloem sap collection from healthy and root (wilt) diseased coconut palms (Coconut nucifera L.). Plant. Physiol. Biochem., 1989, 16(1), 52-56.

35. Coconut Research Institute, Sri Lanka Advisory Circular No. A4 March, 1986, p. 8.

36. Anon., Annual Report of ICAR-CPCRI, Kasaragod, Kerala, India, 2018.

37. Magalon, M., Contribution vl 1': Stude des palmiers de l'Indochine franVVaise, Paris, 1930, pp. 185-191.

38. Fealy, N. E., Quelques Palmiers exploités pour la production de Sucre. Revue de Botanique Appliquée d'Agriculture Coloniale, 1925, 45, 383-387.

39. Piggott, C., Coconut Growing, Oxford University Press, London, 1964.

40. Mathes, D. T., Effect of extraction of inflorescence sap and the removal of immature fruit bunches on the production of female flowers in coconut. Cocos, 1984, 2, 44-47.
41. Maravilla, J. N. and Magat, S. S., Sequential coconut toddy (sap) and nut production (SCTP) in Laguna Tall variety and hybrid coconuts. Phillipine J. Crop Sci., 1993, 18(3), 143-152.

42. Jack, H. W. and Dennet, J. H., The effect of tapping coconut palms for toddy on the copra and oil produced from subsequent fruiting. Malay Agric. J., 1925, 13, 302-308.

43. Chacko Mathew and Ramadasan, A., Photosynthetic efficiency in relation to annual yield and chlorophyll content in the coconut palm. J. Plant. Crops, 1975, 3(1), 26-28.

44. Shivashankar, S., Kasturi Bai, K. V. and Ramadasan, A., A comparative study of coconut genotypes for components of photosynthesis and respiration. In Proceedings of PLACROSYM V, 1982, pp. 231-234.

45. Wasantha, S. M., De Costa, W. A. J. M., Sangakkara, U. R. and Jayasekara, C., Estimation of water use of mature coconut (Cocos nucifera L.) cultivars (CRIC 60 and CRIC 65) grown in the low country intermediate zone using the compensation heat pulse method (CHPM). J. Natl. Sci. Foundation Sri Lanka, 2009, 37(3), $175-186$.

46. Aalbersberg, B., Singh, B. and Ravi, P., Nutrient analysis of coconut toddy. Trop. Sci., 1997, 37(3), 160-163.

47. Anon., Annual Report of ICAR-CPCRI, Kasaragod, Kerala, India, 2014.

48. Anon., Annual Report of ICAR-CPCRI, Kasaragod, Kerala, India, 1985.

49. Chempakam, B., Rajagopal, V. and Gopalam, A., Identification of biochemical constituents in the phloem sap from root (wilt) diseased and apparently healthy coconut palms. Plant Physiol. Biochem., 1991, 18(1), 21-25.

50. Xia, Q., Li, R., Zhao, S., Chen, W., Chen, H. and Xin, B., Chemical composition changes of postharvest coconut inflorescence sap during natural fermentation. Afr. J. Biotechnol., 2011, 10(66), 14999-15005.

51. Nakamura, S. I., Watanabe, A., Chongpraditnum, P., Suzui, N., Hayashi, H. and Mitsuo, C., Analysis of phloem exudate collected from fruit-bearing stems of coconut palm: Palm trees as a source of molecules circulating in sieve tubes. Soil Sci. Plant Nutr., 2004, 50(5), 739-745.

52. Philippine Coconut Authority - Plant and Tissue Analysis Laboratory. Coconuts Today, November 2004, vol. XIX.

53. Kozaki, M., Fermented foods and related micro organisms in Siutheast Asia. Proc. Jpn. Assoc. Mycotoxicol., 1974, 2, 1-10.

54. Augustine, J. and Hebbar, K. B., Coco sap chiller: a new device for the collection of fresh, hygienic and unfermented kalparasa (neera). Patent filed. 5 September 2014, p. 972.

Received 13 July 2018; revised accepted 13 March 2019

doi: $10.18520 / \mathrm{cs} / \mathrm{v} 116 / 111 / 1809-1817$ 